\title{
The role of quantitative electromyography in inclusion body myositis
}

\author{
Thomas H Brannagan, Arthur P Hays, Dale J Lange, Werner Trojaborg
}

\begin{abstract}
Objective and methods-Inclusion body myositis is said to have both myopathic and neurogenic features on electrophysiological tests. Twenty one studies from 20 patients with biopsy defined inclusion body myosis, 13 of whom had quantitative electromyography (qEMG), were reviewed to determine if this technique added diagnostic specificity (one patient had both needle EMG and a later study with qEMG before muscle biopsy).

Results-Excessive numbers of polyphasic motor unit potentials (MUPs) $(>12 \%$ per muscle) were seen in 11 of the 13 patients. In 10 of 13 patients, mean MUP duration was abnormally reduced $(26 \%$ to $48 \%)$. In three patients, mean MUP duration was abnormally reduced only after polyphasic MUPs were excluded. In all 13 patients, the simple MUP duration was reduced. Myopathy was unequivocally diagnosed in all 13 studies that included qEMG; of the remaining eight patients, the conclusions of the electrophysiological studies without qEMG was myopathy (one), neurogenic (four) or non-diagnostic (three).

Conclusions-There is no evidence of a neurogenic component in inclusion body myosis if qEMG is used. Quantitative EMG is often necessary to make an electrophysiological diagnosis of a myogenic disorder in patients with inclusion body myosis.
\end{abstract}

(F Neurol Neurosurg Psychiatry 1997;63:776-779)

Department of

Neurology

T H Brannagan

A P Hays

W Trojaborg

Department of Pathology, Division of Neuropathology, Columbia-Presbyterian Medical Center New

York, NY, USA

D J Lange

Correspondence to: Dr Thomas Brannagan, Department of Neurology, Allegheny

University-Hahnemann

Division, Broad and Vine,

Mail Stop 308, Philadelphia,

PA 19102, USA

Received 7 February 1997 and in revised form

8 May 1997

Accepted 18 June 1997

Keywords: inclusion body myositis; quantitative electromyography; motor neuron disease; fasciculations; motor unit potentials; myopathy

Inclusion body myositis is a chronic inflammatory myopathy, clinically characterised by both proximal and distal limb weakness and a poor response to steroid treatment. Pathologically, the condition is defined by the presence of rimmed vacuoles, filamentous inclusions, and intracellular amyloid deposits. ${ }^{12}$ Electrophysiological studies show features of a myopathy, ${ }^{3}$ but several investigators have reported neurogenic changes, including reduced recruitment and "neurogenic motor unit potentials." "-10

Quantitative EMG (qEMG) separates neurogenic from myogenic disease at least as well as muscle biopsy. ${ }^{11}$ To determine if the use of qEMG enhances the specificity of the physiological findings we reviewed the electrophysiological features of patients with inclusion body myosis, with and without qEMG to determine if there were findings suggestive of a neurogenic component.

\section{Methods}

We reviewed the neurophysiological studies performed at Columbia-Presbyterian Medical Center of 20 consecutive patients with muscle biopsies diagnosed as inclusion body myosis by one of us (APH). Biopsies had features of a myopathy with rimmed vacuoles and inflammatory cells. In selected cases, electron microscopy was performed to identify the characteristic $15-18 \mathrm{~nm}$ filaments. The neurophysiological tests preceded the biopsy in all cases, except for patient 15 as noted in table 2 .

Quantitative EMG was done as previously described. ${ }^{12} 13$ Twenty motor unit potentials (MUPs) were collected with a concentric needle. Band path was $2 \mathrm{~Hz}-20 \mathrm{kHz}$. Duration was measured between the initial deflection of the MUP from the baseline and the terminal return to baseline at a sensitivity of 100 $\mu \mathrm{V} /$ division. Mean duration was calculated for the total number of measured MUPs. Mean duration of simple MUPs (those with fewer than five phases) was calculated separately. Amplitude was measured from peak to peak. Values were considered abnormal when the mean duration deviated by more than $20 \%$ beyond the normal mean duration of the specific muscle, matched for the age of the patient. ${ }^{14}$

All qEMG studies were done by physicians trained and experienced in the technique. The experience of electromyographers performing only routine EMG was equivalent.

\section{Results}

Twenty patients with symptoms for one to 13 years were identified with clinical and electrophysiological features as summarised in tables 1 and 2. Some patients were referred with the diagnosis of ALS and although they did not have definite upper motor neuron signs such as a Babinski's sign or clonus, reflexes were preserved in weak and wasted limbs. All biopsies showed rimmed vacuoles and endomysial fibrosis. Inflammatory cells and groups of atrophic fibres were seen in most cases. Target fibres or fibre type grouping were not seen in any biopsy.

Sensory and motor conduction velocities were normal in all but two patients. Quantitative EMG (qEMG) was performed in 13 patients. Excessive numbers of polyphasic MUPs were seen in 11 patients ( $15 \%$ to $60 \%$ ). In 10 of these patients, the mean duration of all 
Table 1 Clinical characteristics

\begin{tabular}{|c|c|c|}
\hline $\operatorname{Sex}(M: F)$ & $14: 6$ & \\
\hline Mean age at onset (range) (y) & 62 & $(44-73)$ \\
\hline \multicolumn{2}{|l|}{ Duration of symptoms (mean } & $(1-13)$ \\
\hline Patients given diagnosis of ALS & 7 & \\
\hline Cramps & 0 of 10 & \\
\hline \multicolumn{3}{|l|}{ Symptoms at onset (n (\%)): } \\
\hline Legs & 13 of 20 & 65 \\
\hline Arms & 6 of 20 & 30 \\
\hline Dysphagia & 2 of 20 & 10 \\
\hline Asymmetry at onset (n (\%)) & 5 of 20 & 25 \\
\hline $\begin{array}{l}\text { Finger flexor weakness or atrophy ( } \mathrm{n} \\
(\%))\end{array}$ & 13 of 20 & 65 \\
\hline $\begin{array}{l}\text { Quadriceps weakness or atrophy (n } \\
(\%) \text { ) }\end{array}$ & 17 of 20 & 85 \\
\hline Neck weakness (n (\%)) & 3 of 11 & 27 \\
\hline Bulbar symptoms (n (\%)) & 6 of 19 & 32 \\
\hline Facial weakness (n (\%)) & 7 of 18 & 39 \\
\hline $\begin{array}{l}\text { Mean serum CK (X upper limit of } \\
\text { normal) }\end{array}$ & 4.1 & $0.7-12.9$ \\
\hline Response to IVIG (minimal) & 4 of 7 & \\
\hline Response to prednisone & 2 of 9 & \\
\hline Response to azathioprine (imuran) & 0 of 3 & \\
\hline
\end{tabular}

MUPs was abnormally reduced by $26 \%$ to $48 \%$. In three patients, the mean duration of all MUPs was normal, but it was abnormally reduced if only simple MUPs were considered ( $34 \%$ to $46 \%$ below the normal mean; table 3 ).
Therefore a myogenic disorder was diagnosed in all 13 studies in which qEMG was done. Of the remaining eight studies, when formal analysis of MUP form was not undertaken the findings were interpreted as neurogenic (four), including three as motor neuron disease or non-diagnostic (three). In only one of eight patients was a myogenic disorder correctly diagnosed (table 3). In one patient (10), the EMG was interpreted as showing motor neuron disease, without using quantitative EMG; when repeated five months later, qEMG disclosed short duration MUPs compatible with myopathy.

Eleven of the 20 patients with inclusion body myosis were referred to us with the diagnosis of motor neuron disease or neuropathy. A myogenic disorder was diagnosed in all five in whom qEMG was done. In only one of the six patients tested without qEMG was the myogenic nature of the illness identified using physiological methods.

Two patients (6 and 13), with EMG evidence of fasciculations, had biopsies of the motor nerve to the gracilis muscle to consider the possible coexistence of a motor neuropathy.

Table 2 Electrodiagnostic results from 20 patients with inclusion body myositis

\begin{tabular}{|c|c|c|c|c|c|c|c|c|c|c|c|c|}
\hline $\begin{array}{l}\text { Patient } \\
\text { No }\end{array}$ & $\begin{array}{l}\text { Referring } \\
\text { diagnosis }\end{array}$ & $\begin{array}{l}E M G \\
\text { diagnosis }\end{array}$ & $M N C$ & $S N C$ & Muscle & $\underset{(n)}{M U P s}$ & $\begin{array}{l}\text { Polys } \\
\text { (\%) }\end{array}$ & $\begin{array}{l}\text { Duration } \\
\text { (ms) } \% \\
\text { normal) }\end{array}$ & $\begin{array}{l}\text { Duration of } \\
\text { simple MUPS } \\
\text { (\% of } \\
\text { normal) }\end{array}$ & $\begin{array}{l}\text { Amplitude } \\
(\mu V)\end{array}$ & $\begin{array}{l}\text { Spontaneous } \\
\text { activity }\end{array}$ & Recruitment \\
\hline 1 & IBM & Myopathy & $\mathrm{N}$ & $\mathrm{N}$ & Tib ant & 20 & 15 & $\begin{array}{ll}10 \quad(68) \\
\end{array}$ & $9.9(67)$ & 330 & $1+$ fibs & 4,6 \\
\hline 2 & ALS & Myopathy & $\downarrow_{\mathrm{a}}(\mathrm{p})$ & $\mathrm{N}$ & Ttib ant & 20 & 30 & $9.5(62)$ & $8.8(57)$ & 496 & $\begin{array}{l}1-3+\text { fibs/ } \\
1+\text { fascics }\end{array}$ & $2,5,6$ \\
\hline 3 & MND & Myopathy & $\mathrm{N}$ & $\mathrm{N}$ & $\begin{array}{l}\text { Vas lat } \\
\text { Biceps } \\
\text { Deltoid }\end{array}$ & $\begin{array}{l}28 \\
24 \\
25\end{array}$ & $\begin{array}{l}21 \\
0 \\
8\end{array}$ & $\begin{array}{l}11.3(73) \\
10.2(84) \\
11.9(96)\end{array}$ & $\begin{array}{l}10.6(69) \\
10.2(84) \\
11.4(93)\end{array}$ & $\begin{array}{l}329 \\
147 \\
215\end{array}$ & $1+$ fibs & 1,4 \\
\hline 4 & $\operatorname{ALS} v \mathrm{~N}$ & Myopathy & $\mathrm{N}$ & $\mathrm{N}$ & Vas lat & 17 & 12 & $17.6(114)$ & $17.7(115)$ & 910 & $\begin{array}{l}2+\text { fibs/ } \\
1+\text { fascics }\end{array}$ & $1,3,4,5$ \\
\hline 5 & $\mathrm{PM}$ & Myopathy & $\mathrm{N}$ & $\mathrm{N}$ & $\begin{array}{l}\text { Tib ant } \\
\text { Biceps }\end{array}$ & $\begin{array}{l}15 \\
20\end{array}$ & $\begin{array}{l}15 \\
10\end{array}$ & $\begin{array}{l}7.8(52) \\
7.7(60)\end{array}$ & $\begin{array}{l}6.4(43) \\
7.9(62)\end{array}$ & $\begin{array}{l}641 \\
419\end{array}$ & $2+$ fibs & 4 \\
\hline 6 & Myopathy & Myopathy & $\mathrm{N}$ & $\mathrm{N}$ & Biceps & 20 & 10 & $8.4(74)$ & $8.5(75)$ & & $\begin{array}{l}1-2+\text { fibs/ } \\
\text { fascics/myo- } \\
\text { kymia/CRDS }\end{array}$ & 5 \\
\hline 7 & Myopathy & Myopathy & $\mathrm{N}$ & $\mathrm{N}$ & Biceps & 20 & 50 & $8.4(68)$ & $8.4(68)$ & 227 & $1-2+$ fibs & 4,6 \\
\hline 8 & PM & Myopathy & $\mathrm{N}$ & $\mathrm{N}$ & Biceps & 20 & 25 & $8.1(65)$ & $\begin{array}{l}7.4(60) \\
7.400\end{array}$ & 514 & fibs & 4 \\
\hline 9 & Myopathy & Myopathy & $<\mathrm{a}(\mathrm{t})$ & $\mathrm{N}$ & Vas lat & 18 & 44 & $9.6(62)$ & $9.4(60)$ & 749 & $\begin{array}{l}1+\text { fibs/ } \\
2+\text { fascics/C } \\
\text { RDS }\end{array}$ & $1,2,4,6$ \\
\hline 10 & $\begin{array}{l}\text { SMA } v \\
\text { myopathy }\end{array}$ & MND & $\begin{array}{l}\downarrow_{\mathrm{a}}(\mathrm{u}, \mathrm{p}, \mathrm{t}) \\
\downarrow_{\mathrm{cv}(\mathrm{t})}\end{array}$ & $\downarrow C V(m, u, s)$ & & & $\mathrm{P}$ & Long & & & $\begin{array}{l}1-2+\text { fibs/ } \\
1-2+\text { fascics/ } \\
\text { CRDS }\end{array}$ & 2,3 \\
\hline & SMA & Myopathy & Not done & Not done & $\begin{array}{l}\text { Biceps } \\
\text { Vas lat }\end{array}$ & $\begin{array}{l}21 \\
18\end{array}$ & $\begin{array}{l}24 \\
39\end{array}$ & $\begin{array}{r}8.4(68) \\
11.3(72)\end{array}$ & $\begin{array}{r}6.7(54) \\
11.6(74)\end{array}$ & $\begin{array}{l}193 \\
374\end{array}$ & rare fibs/CRDS & 2,4 \\
\hline 11 & Myopathy & Myopathy & $\downarrow_{\mathrm{a}(\mathrm{p})}$ & $\mathrm{N}$ & Tib ant & 20 & 30 & $20 \quad(136)$ & 8 (54) & 455 & $2+f i b s$ & $1,2,5$ \\
\hline 12 & Myopathy & Myopathy & $\mathrm{N}$ & $\mathrm{N}$ & $\begin{array}{l}\text { Vas lat } \\
\text { Tib ant }\end{array}$ & $\begin{array}{l}28 \\
22\end{array}$ & $\begin{array}{l}29 \\
50\end{array}$ & $\begin{array}{l}14.9(102) \\
12.7(89)\end{array}$ & $\begin{array}{r}13.9(95) \\
9.4(66)\end{array}$ & $\begin{array}{l}729 \\
358\end{array}$ & $1+$ fibs & 1,2 \\
\hline 13 & ALS & Myopathy & $\mathrm{N}$ & $\mathrm{N}$ & Biceps & 20 & 60 & $11.3(98)$ & $6.9(60)$ & 589 & $\begin{array}{l}\text { 1-2+fibs/ } \\
\text { fascics/CR DS }\end{array}$ & 5 \\
\hline 14 & ALS & MND & $\mathrm{N}$ & $\mathrm{N}$ & & - & $\mathrm{P}$ & Long & & I & $\begin{array}{l}1-2+\text { fibs } / \\
1-3+\text { fascics }\end{array}$ & 2,3 \\
\hline 15 & ALS & SMN & $\downarrow_{\mathrm{a}(\mathrm{u}, \mathrm{p})}$ & $\begin{array}{l}\downarrow \mathrm{dV}(\mathrm{m}, \mathrm{u}, \mathrm{s}), \\
<\mathrm{a}(\mathrm{m}, \mathrm{u})\end{array}$ & & - & $\mathrm{P}$ & & & I & $1-2+$ fibs/fascics & 2,3 \\
\hline \multirow[t]{3}{*}{$\begin{array}{r}\text { After } \\
\text { bx }\end{array}$} & ALS $v \mathrm{~N}$ & SMN & $\begin{array}{l}\downarrow \mathrm{CV}(\mathrm{m}, \\
\mathrm{p}),<\mathrm{a}(\mathrm{p})\end{array}$ & $\begin{array}{l}\downarrow_{\mathrm{cv}, \mathrm{a}(\mathrm{m}, \mathrm{u})} \\
\mathrm{ab}(\mathrm{s})\end{array}$ & & - & $\mathrm{P}$ & & & I & $\begin{array}{l}1-2+\text { fibs/ } \\
1+\text { fascics }\end{array}$ & 2,3 \\
\hline & Myopathy & $\begin{array}{l}\text { Myo/ } \\
\text { SMN }\end{array}$ & $\downarrow_{\mathrm{a}}(\mathrm{p}, \mathrm{t})$ & $\begin{array}{l}\downarrow \mathrm{CV}, \mathrm{a}(\mathrm{m}), \\
\mathrm{ab}(\mathrm{s})\end{array}$ & & - & $\mathrm{P}$ & $\mathrm{R}$ & & $\mathrm{R}, \mathrm{I}$ & $1-2+$ fibs & 2,4 \\
\hline & Myopathy & $\begin{array}{l}\text { Myo/ } \\
\text { SMN }\end{array}$ & $\begin{array}{l}\downarrow \mathrm{CV}(\mathrm{p}, \mathrm{t}), \\
\downarrow_{\mathrm{a}(\mathrm{p}, \mathrm{t})}\end{array}$ & $\begin{array}{l}\downarrow \mathrm{CV}, \mathrm{a}(\mathrm{m}, \mathrm{u}), \\
\mathrm{ab}(\mathrm{s})\end{array}$ & & - & & & & & & \\
\hline 16 & $\begin{array}{l}\operatorname{IBM} v \\
M N D\end{array}$ & Myopathy & $\mathrm{N}$ & $\mathrm{N}$ & & & $\mathrm{N}$ & $\mathrm{R}$ & & $\mathrm{R}$ & $1+$ fibs & 2,4 \\
\hline 17 & $\mathrm{PM} v \mathrm{PN}$ & Non-diag & $\mathrm{N}$ & $\mathrm{N}$ & & - & $\mathrm{P}$ & $\mathrm{N}$ & & $\mathrm{N}$ & None & 2 \\
\hline 18 & MND & MND & $\mathrm{N}$ & $\mathrm{ab}(\mathrm{s})$ & & - & $\mathrm{P}$ & & & I & $1-2+$ fibs & $1,2,4,6$ \\
\hline 19 & Myopathy & Normal & $\mathrm{N}$ & $\mathrm{N}$ & & - & $\mathrm{N}$ & $\mathrm{N}$ & & $\mathrm{N}$ & None & 1 \\
\hline 20 & Myositis & Normal & $\mathrm{N}$ & $\mathrm{Ab}(\mathrm{s})$ & & - & $\mathrm{N}$ & $\mathrm{N}$ & & $\mathrm{N}$ & None & 1,6 \\
\hline
\end{tabular}

$\mathrm{a}=\mathrm{amplitude} ; \mathrm{ab}=\mathrm{absent}$; ALS=amyotrophic lateral sclerosis; $\mathrm{CRDS}=$ complex repetitive discharges; fascics=fasciculations; fibs=fibrillations and positive sharp waves; $\mathrm{CV}=$ conduction velocity; I=increased; IBM=inclusion body myositis; $\mathrm{m}=$ median nerve; $\mathrm{MND}=$ motor neuron disease; $\mathrm{N}=$ normal; $\mathrm{np}=$ neuropathy; $\mathrm{p}=$ peroneal; $\mathrm{PM}=$ polymyositis; $\mathrm{R}=$ reduced; $\mathrm{s}=$ sural; $\mathrm{SMA}=$ spinal muscular atrophy; $\mathrm{SMN}=$ sensorimotor neuropathy; $\mathrm{t}=$ tibial nerve; $\mathrm{u}=\mathrm{ulnar}$ nerve; $1=$ =full recruitment on maximal effort; $2=$ reduced recruitment on maximal effort; $3=$ discrete recruitment on maximal effort; $4=$ full recruitment on submaximal effort; $5=$ full recruitment on maximal effort in a weak muscle; $6=$ reduced recruitment on submaximal effort. 
Table 3 Electrophysiological findings

\begin{tabular}{|c|c|}
\hline Findings & $n(\%)$ \\
\hline \multicolumn{2}{|l|}{ Nerve conduction: } \\
\hline Reduced CMAP & $5(25 \%)$ \\
\hline Slow motor and sensory conduction velocity & $2(10 \%)$ \\
\hline \multicolumn{2}{|l|}{ EMG: } \\
\hline Fasciculations & $8(40 \%)$ \\
\hline Fibrillations/Positive sharp waves & $17(85 \%)$ \\
\hline Myokymia & $1(5 \%)$ \\
\hline Complex repetitive discharges & $4(20 \%)$ \\
\hline \multicolumn{2}{|l|}{ Quantitative EMG in 13 patients: } \\
\hline Increased polyphasics $(15-60 \%)$ & $11(85 \%)$ \\
\hline Short mean duration - all MUPs ( $26-48 \%$ ) & $10(77 \%)$ \\
\hline $\begin{array}{l}\text { Short mean duration - simple MUPs } \\
(34-46 \%)\end{array}$ & $13(100 \%)$ \\
\hline $\begin{array}{l}\text { Quantitative EMG and diagnosis of myopathy: } \\
\qquad E M G \\
\text { done }\end{array}$ & $\begin{array}{l}q E M G \text { not } \\
\text { done }\end{array}$ \\
\hline Diagnosis of myopathy & 1 \\
\hline No diagnosis of myopathy & 7 \\
\hline
\end{tabular}

The motor nerve was morphologically normal in both and immunohistochemistry for nerve growth factor receptor was absent in one (6) and in the other there was only trace expression (13).

\section{Discussion}

Claims of a neuropathic component in inclusion body myosis have been based on features from muscle biopsy and electrophysiological testing. Group atrophy and angular fibres are seen which are suggestive although not specific for a neurogenic disorder. Fibre type grouping, which is specific for a neurogenic disorder, is generally not seen ${ }^{4910}$ unless there is a concomitant neuropathy as occurred in three of 48 patients in one series. ${ }^{3}$ Long duration or "neurogenic" MUPs on EMG are also cited as evidence of a neurogenic component in inclusion body myosis. ${ }^{4-9}$ In fact, long duration polyphasic MUPs are characteristically found in chronic myogenic disease. ${ }^{15}{ }^{16}$ Fibrillations and positive sharp waves are often seen in myopathy ${ }^{17}$ and fasciculations are also occasionally seen in various muscle diseases. ${ }^{18}$ One report found fasciculations in $10 \%$ of patients with inclusion body myosis. ${ }^{3}$ Our findings, therefore, do not support the presence of a neurogenic component in inclusion body myosis if $\mathrm{qEMG}$ is employed.

Nerve conduction studies were normal except for mildly decreased evoked response amplitude in five of our patients, compatible with muscle atrophy, which may result from a myopathy. Sensory and motor conduction velocities were normal in all but two. One patient (15) had a coexisting neuropathy with sensory loss, absent ankle reflexes, and a raised CSF protein content. Nerve biopsy disclosed a severe neuropathy with rare onion bulbs. The second patient (10), a 68 year old woman with no sensory complaints, had mild slowing of the median, ulnar, and sural sensory nerves and the tibial motor nerve. The amplitude of the sensory responses was normal however, and low skin temperature was the implicated cause. The abnormalities on conduction studies in these two patients, therefore, can be explained by factors other than implicating neurogenic involvement of inclusion body myosis.
Reduced recruitment is a qualitative measurement, but is also non-specific because it may be seen in myopathies when loss of fibres is so extensive that whole motor units drop out. ${ }^{19}$

The presence of long duration polyphasic MUPs seen in myopathies correlate with regenerating fibres. ${ }^{16}$ Patients with neuropathic, myopathic, or normal EMG may have individual MUPs that could be considered "neuropathic" (>16 ms) or "myopathic" $(<6 \mathrm{~ms}) \cdot{ }^{13}{ }^{20}$ Only the mean duration of a sufficient number of simple MUPs correlates with the presence of a neuropathy or myopathy. ${ }^{11}$ In one report of eight patients with inclusion body myosis, no patients showed neuropathic changes using quantitative EMG. ${ }^{21}$ Studies using single fibre $E M G^{22}$ and macro-EMG ${ }^{23}$ in patients with inclusion body myosis also found no evidence of a neuropathic process or reinnervation as a cause of the long duration polyphasic motor units seen.

Quantitative EMG is necessary to accurately characterise the myogenic motor unit morphology in some cases of inclusion body myosis. Without qEMG, in the presence of spontaneous activity (fibrillations, positive sharp waves, and fasciculations), long duration polyphasic MUPs, and reduced recruitment, a pure motor neurogenic disorder, such as motor neuron disease, may be erroneously suspected.

We thank Dr Lewis P Rowland for helpful comments on the manuscript. Presented in part in abstract form at the meeting of the American Neurology Association, Washington, DC, 22-25 October 1995

1 Griggs RC, Askanas V, DiMauro S, Engel A, Karpati G, Mendell JR, Rowland LP. Inclusion body myositis and myopathies. Ann Neurol 1995;38:705-12.

2 Dalakas MC. Polymyositis, dermatomyositis, and inclusion body myositis. N Engl f Med 1991;325:1487-98.

3 Lotz BP, Engel AG, Nishino H, Stevens JC, Litchy WJ. Inclusion body myositis. Brain 1989;112:727-47.

4 Carpenter S, Karpati G, Heller I, Eisen A. Inclusion body myositis: a distinct variety of idiopathic inflammatory myopathy. Neurology 1978;28:8-17.

5 Danon MJ, Reyes MG, Perurena OH, Masdeu JC, Manaligod JR. Inclusion body myositis: a corticosteroid-resistant
idiopathic inflammatory myopathy. Arch Neurol 1982;39: 160path.

6 Eisen A, Berry K, Gibson G. Inclusion body myositis (IBM): myopathy or neuropathy? Neurology 1983;33:110914.

7 Joy JL, Oh SJ, Baysal AI. Electrophysiological spectrum of inclusion body myositis. Muscle Nerve 1990;13:949-51.

8 Lindberg $\mathrm{C}$, Oldfors $\mathrm{A}$, Hedström A. Inclusion body myositis: peripheral nerve involvement combined morphoogical and electrophysiological studies on peripheral nerves. F Neurol Sci 1990;99:327-38.

9 Lindberg C, Persson L, Bjorkander J, Oldfors A. Inclusion body myositis: clinical, morphological, physiological and laboratory findings in 18 cases. Acta Neurol Scand 1994;89: 123-31.

10 Mhiri C, Gherardi R. Inclusion body myositis in French patients. A clinicopathological evaluation. Neuropathol Appl

11 Buchthal F, Kamieniecka Z. The diagnostic yield of quantified electromyography and quantified muscle biopsy in neuromuscular disorders. Muscle Nerve 1982;5:265-80.

12 Buchthal F, Pinelli P. Analysis of muscle action potentials as a diagnostic aid in neuromuscular disorders. Acta Med Scand 1952; (suppl 266):315-27.

13 Trojaborg W. Quantitative electromyography in polymyositis: a reappraisal. Muscle Nerve 1990;13:964-71.

14 Rosenfalck P, Rosenfalck A. Electromyography, sensory and motor conduction: findings in normal subjects. Laboratory of Clinical Neurophysiology. Copenhagen: Rigshospitalet, 1975:1-49.

15 Uncini A, Lange DJ, Lovelace RE, Solomon M, Hays AP. Long-duration polyphasic motor unit potentials in myopathies: a quantitative study with pathological correlation. Muscle Nerve 1990;13:263-7. 
16 Barkhaus PE, Nandedkar SD, Sanders DB. Quantitative EMG in inflammatory myopathy. Muscle Nerve 1990;13: 247-53.

17 Streib EW, Wilbourn AJ, Mitsumoto H. Spontaneous electrical muscle fiber activity in polymyositis and dermatomyositis. Muscle Nerve 1979;2:14-8.

18 Howard RS, Murray NM. Surface EMG in the recording of fasciculations. Muscle Nerve 1992;15:1240-5.

19 Buchthal F. Electromyography in the evaluation of muscle diseases. Neurol Clin 1985;3:573-98.
20 Buchthal F, Guld C, Rosenfalck P. Action potential parameters in normal human muscle and their dependence on physical variables. Acta Physiol Scand 1954;32:200-18.

21 Barkhaus PE. Quantitative EMG studies in inclusion body myositis. F Neurol Sci 1990;98(suppl): 180 .

$22 \mathrm{Oh}$ SJ, Claussen GC. Single-fiber EMG findings in inclusion body myopathy. Muscle Nerve 1995;18:1050.

23 Luciano CA, Dalakas MC. Inclusion-body myositis: no evidence for a neurogenic component. Neurology 1997;48:2933.

\section{Fournal of Neurology Neurosurgery and Psychiatry - http://www.jnnp.com}

Visitors to the world wide web can now access the fournal of Neurology Neurosurgery and Psychiatry either through the BMJ Publishing Group's home page (http://www.bmjpg.com) or directly by using its individual URL (http://www.jnnp.com). There they will find the following:

- Current contents list for the journal

- Contents lists of previous issues

- Members of the editorial board

- Subscribers' information

- Instructions for authors

- Details of reprint services.

A hotlink gives access to:

- BMJ Publishing Group home page

- British Medical Association web site

- Online books catalogue

- BMJ Publishing Group books.

The web site is at a preliminary stage and there are plans to develop it into a more sophisticated site. Suggestions from visitors about features they would like to see are welcomed. They can be left via the opening page of the BMJ Publishing Group site or, alternatively, via the journal page, through "about this site". 